Jurnal Konstruksi Hukum | ISSN: 2746-5055

Vol. 2, No. 2, Mei 2021, Hal. 277-282| Tersedia online di

https://www.ejournal.warmadewa.ac.id/index.php/jukonhum

DOI: https://doi.org/10.22225/jkh.2.2.3222.277-282

\title{
PENANGANAN KREDIT SEBAGAI KEBIJAKAN COUNTERCYCLICAL DAMPAK PENYEBARAN CORONA VIRUS DISEASE 2019 BERDASARKAN PERATURAN OTORITAS JASA KEUANGAN NOMOR 11/POJK.03/2020 DI PT BPR SAPTACRISTY UTAMA
}

\author{
Kadek Dani Arditha Permana, I Nyoman Putu Budiartha, Ni Made Puspasutari Ujianti \\ Fakultas Hukum Universitas Warmadewa, Denpasar-Bali, Indonesia \\ daniarditha86@gmail.com, budiarthaputu@gmail.com, puspasutariujianti@gmail.com
}

\begin{abstract}
Abstrak
Penyebaran dan pertumbuhan Virus Corona di Indonesia secara langsung ataupun tidak langsung memberikan pengaruh terhadap kinerja serta kapabilitas debitur, termasuk debitur mikro, kecil, serta menengah. Hal tersebut hendak menghambat kinerja bank serta stabilitas sistem keuangan yang bisa pengaruhi perkembangan ekonorni. Berdasarkan pertimbangan tersebut, Otoritas Jasa Keuangan menerbitkan Peraturan Otoritas Jasa Keuangan Nomor 11/POJK.03/2020 Tentang Stimulus Perekonomian Nasional Sebagai Kebijakan Countercyclical Darnpak Corona Virus Disease 2019. Tujuan penelitian ini adalah untuk mengetahui bagaimana kebijakan Otoritas Jasa Keuangan dalam menangani kredit macet akibat Covid-19. Metode dalam penelitian ini dilakukan dalam tulisan ilmiah ini adalah dengan metode empiris yakni penelitian hukurn berdasarkan keadaan secara langsung di lapangan. Hasil penelitian adalah hal yang belum diatur dalam perjanjian kredit dapat dirubah dan atau ditambahkan dengan menggunakan perjanjian tarnbahan atau addendum. Dalam Penerapan Peraturan Otoritas Jasa Keuangan Nomor 11/POJK.03/2020, Otoritas Jasa Keuangan mengharuskan setiap bank untuk membuat pedoman untuk menetapkan debitur yang terdampak penyebaran Corona Virus Disease 2019 (COVID-19) yang dirnana setiap bank akan mempunyai kebijakan berbeda-beda dalam penanganan kredit debiturnya.
\end{abstract}

Kata Kunci: Countercyclical, Otoritas Jasa Keuangan, Virus Korona

\begin{abstract}
The spread and growth of the Corona Virus in Indonesia directly and indirectly affect the performance and the capacity of micro, small, as well as medium business debtors. Therefore, it may undermine bank performance and financial system stability, thereby affecting economic growth. Based on these considerations, the Financial Services Authority (Otoritas Jasa Keuangan) issued the Financial Services Authority regulation number 11 /POJK/03/2020 which regard National Economic Stimulus as a Countercyclical Policy for the impact of Corona Virus Disease 2019. The purpose of this research is to find out how the Financial Services Authority's policies are in dealing with bad credit due to Covid-19. The research method that carried out in this scientific paper is the empirical method, namely legal research based on actual conditions in the field. The results of this research are the things that have not been regulated in the credit agreement can be changed and or added by using an additional agreement or addendum. In the Financial Services Authority Implementation Regulation No. $l$ l/POJK.03/2020, the Financial Services Authority requires every bank to formulate guidelines to designate debtor's affectively the spread of Coronavirus Disease 2019. Each bank will have different policies for handling the credit of its debtor's.
\end{abstract}

Keywords: Countercyclical, Financial Services Authority, Corona Virus

\section{PENDAHULUAN}

Bank merupakan lembaga keuangan yang dipercaya oleh masyarakat dan memegang peranan penting dalam sistem perekonomian.Oleh karena itu, bank dapat dikatakan sebagai pintu gerbang dari semua kegiatan dalam pergerakan perekonomian, dan tujuan dari semua kegiatan adalah untuk menerima simpanan masyarakat dari tempat umum. Dalam bentuk tabungan, deposito atau giro, kemudian diubah menjadi dana yang dihimpun dari masyarakat dan dikembalikan kepada masyarakat dalam bentuk kredit. 
Indonesia perkembangan bisnis perbankan akhir-akhir ini mengalami pasang surut dan cenderung menurun. Bank sebagai perantara keuangan merupakan instrumen penunjang, membantu kelancaran fungsi perekonomian dalam fungsinya menyalurkan dana dari penabung kepada peminjam (Bahsan, 2001:75).

Undang-Undang Republik Indonesia Nomor 10 Tahun 1998 tentang Undang-undang Nomor 7 Tahun 1992 tentang Perbankan, Pasal 1 ayat (11) menjelaskan tentang pengertian kredit dapat diartikan sebagai bank yang memberikan valuta atau padanan sepadan dengan perjanjian pinjaman dan lainnya. Perjanjian atau perjanjian antara para pihak yang mengharuskan pihak tersebut untuk membayar kembali hutang dengan bunga setelah jangka waktu tertentu. Pemberian kredit dari bank kepada nasabah debitur didasarkan pada perjanjian kredit, perjanjian kredit berisi kesepakatan tentang hak dan kewajiban masingmasing pihak antara bank dan debitur (Mulyati, 2016). Pada prinsipnya bank baru memutuskan memberikan kreditapabila bank telah memperoleh keyakinan tentangkelayakan usaha dan nasabahnya (Hamzah, 2019).

Pandemi Corona Virus Disease 2019 (COVID-19) memberikan dampak yang sangat besar bagi pertumbuhan ekonomi dan stabilitas keuangan di Indonesia, terutama bagi pelaku usaha kecil, mikro, dan menengah. Sehubungan dengan hal tersebut banyak usaha debitur pada sektor-sektor tertentu memiliki kesulitan dalam memenuhi kewajibannya sebagai debitur untuk membayar kredit atau pembiayaannya. Tentang ini jelas tingkatkan resiko kredit serta bisa mengganggu kinerja bank serta stabilitas sistem keuangan sehingga pengaruhi perkembangan ekonomi.

Atas dasar tersebut, untuk menekan optimalisasi guna intermediasi perbankan serta melindungi stabilitas sistem keuangan dengan memberikan perlakuan eksklusif bagi debitur dengan pembiayaan kredit, kebijakan stimulus ekonomi butuh diadopsi selaku countercyclical penyebaran dari Corona Virus Disease 2019 (COVID 19). Oleh karena itu, Otoritas Jasa Keuangan mengatur Peraturan Otoritas Jasa Keuangan Nomor 1 1/POJK.03/2020 Tentang Stimulus Perekonomian Nasional Sebagai Kebijakan Countercyclical Dampak Penyebaran Corona Virus Disease 2019 yang di-sahkannya pada tanggal 16 Maret 2020.

Pada prinsipnya Peraturan Otoritas Jasa Keuangan tersebut berlaku untuk Bank Umum Konvensional, Bank Umum Syariah, Unit Usaha Syariah (UUS), Bank Perkreditan Rakyat (BPR), dan Bank Pembiayaan Rakyat Syariah (BPRS) di PT. BPR Saptacristy Utama memutuskan untuk menerapkan beberapa kebijakan untuk mendukung kebijakan pertumbuhan ekonomi karena beberapa debitur yang berada di PT. BPR Saptacristy Utama memiliki fasilitas kredit secara langsung maupun tidak langsung terkena dampak penyebaran Corona Virus Disease 2019 (COVID-19). Sehubungan dengan hal tersebut penulis tertarik untuk melakukan penelitian tentang pelaksanaan penanganan kredit macet berdasarkan kebijakan stimulus yang mendukung pertumbuhan ekonomi yang diterapkan di PT. BPR Saptacristy Utama. Khusus untuk debitur yang terkena dampak pandemi COVID-19. Berdasarkan uraian diatas, maka penulis mengambil judul dalam karya ilmiah ini adalah Penanganan Kredit Sebagai Kebijakan Countercyclical Dampak Penyebaran Corona Virus Disease 2019 Berdasarkan Peraturan Otoritas Jasa Keuangan Nomor 1 1/POJK.03ffahun 2020 di PT. BPR Saptacristy Utama. Tujuan penelitian ini adalah untuk mengetahui bagaimana kebijakan Otoritas Jasa Keuangan dalam menangani kredit macet akibat COVID-19.

\section{METODE PENELITIAN}

Metode penelitian yang digunakan pada karya ilmiah hukum ini adalah metode penelitian empiris. Penelitian Metode Empiris ialah metode riset hukum yang memakai fakta-fakta yang diperoleh dari wawancara, observasi, ataupun sikap manusia secara langsung. Tidak hanya itu, riset empiris dapat digunakan buat mengamati hasil dari tingkah laku manusia berupa peninggalan aset raga ataupun arsip (Fajar \& Achmad, 2010). Cara pengambilan data pada penelitian ini adalah dengan cara melakukan interview kepada Bapak Dewa Ketut Kusuma Dewa, selaku Kepala Bagian Kredit di PT. BPR Saptacristy Utama dan menggunakan bahan hukum yang berisi peraturan-peraturan yang mengikat. 


\section{HASIL DAN PEMBAHASAN}

\section{Implikasi Peraturan Otoritas Jasa Keuangan Nomor 11/POJK.03/2020 terhadap Perjanjian Kredit} Perjanjian kredit merupakan salah satu aspek yang sangat penting dalam pemberian kredit (Hidayat, 2014). Perjanjian kredit umumnya merupakan perjanjian prinsip (principal). Selaku transaksi nyata (riil), perrjanjian pokok merupakan lampiran. Adanya dan pengakhiran perjanjian pokok tergantung pada konvensi utama. Makna riil, ialah terjadinya suatu perjanjian kredit tergantung pada penyerahan dana bank kepada debitur (Hermansyah, 2005).

Berdasarkan kejadian tersebut, terjalin hubungan hukum antara para pihak yang menandatanganiperjanjian. Hubungan hukum tersebut sejenis perjanjian yang menjadi dasar bagi salah satu pihak untuk meminta pihak lain wajib memenuhi persyaratan pihak lainnya, begitu pula sebaliknya (Kosasih, 2004: 19). Dalam pengertian ini, dasar hukum perjanjian kredit Pasal 8 Undang-Undang Nomor 10 Tahun 1998 Tentang perubahan atas Undang-Undang Nomor 7 Tahun 1992 tentang Perbankan didasarkan pada analisis mendalam atas maksud dan kemampuan debitur, kemampuan untuk memberikan kredit atau pembiayaan untuk melunasi hutang atau mengembalikan pembiayaan tersebut diatas.

Menurut hukum, perjanjian kredit dapat dibuat dengan cara lisan atau tertulis yang terpenting telah memenuhi syarat-syarat pasal 1320 KUHPerdata. Namun dari segi pembuktiannya perjanjian secara lisan akan sulit untuk dijadikan sebagai alat bukti bagi para pihak yang membuatnya. Tentunya meskipun secara teoritis diperbolehkan, namun tidak disarankan lagi untuk menggunakannya dalam pengembangan teknologi yang kompleks ini, karena sulit menggunakan kesepakatan lisan sebagai bukti ketika timbul masalah di kemudian hari. Oleh karena itu, setiap kesepakatan harus dalam bentuk tertulis sebagai akta sebagai bukti. Bentuk perjanjian kredit di dalam prakteknya dapat dibagi menjadi dua:

Perjanjian kredit yang ditandatangani itikad dari perjanjian kredit yang ditandatangani merupakan perjanjian yang dibuat serta dirumuskan oleh pihak bank serta setelah itu diserahkan kepada debitur perjanjian tersebut. Guna memudahkan kinerja bank, bank umumnya mempersiapkan bentuknya sesuai standarnya (Standard Form)

Perjanjian kredit yang dibuat diantara notaris dengan kedua belah pihak (Akta Otentik atau Akta Notari) (Sutarno, 2005: 100)

Pihak yang menandatangani perjanjian kredit dapat jadi notaris, dapat pula dihadirat notaris, ataupun dapat disimpulkan dan didaftarkan dengan notaris. Namun nyatanya, ketentuan serta syarat perjanjian kredit tersebut disediakan dengan bank serta setelah itu diajukan ke notaris hendak mendapatkan persetujuan. Kontrak ini biasanya digunakan untuk memberikan pinjaman dalam jumlah besar dalam jangka menengah dan panjang, seperti pinjaman modal kerja, pinjaman sindikasi dan pinjaman investasi. Berdasarkan hasil penelitian dengan lbu Kadek Anita Dewi, Direksi Pf. BPR Saptacristy Utama menyatakan pada 19 November 2020 bahwa secara umum perjanjian kredit bank ditandatangani, dibuat dan dirumuskan oleh bank, kemudian diberikan kepada debitur dengan menyiapkan formulir perjanjian kredit untuk mencapai kesepakatan.

Dalam Pengaturan Peraturan Otoritas Jasa Keuangan Nomor 11/POJK.03/2020 Bank diperbolehkan melaksanakan kebijakan yang membantu stimulus pertumbuhan ekonomi untuk debitur yang terkena dampak penyebaran COVID-19 termasuk debitur UMKM dengan tetap memperhatikan prinsip kehati-hatian. Perbankan dalam sektor perekonomian dapat dikatakan sebagai usaha yang penuh resiko, sebelum suatu bank memberikan kualitas kredit, seharusnya bank melakukan survey kepada debitur dengan cermat apakah debitur layak diberikan fasilitas kredit atau tidak. Bank harus meyak: ini bahwa kredit yang akan diberikan tersebut dapat dilunasi kembali pada waktunya oleh nasabah debitur dan tidak akan berkembang menjadi kredit yang bermasalah atau kredit macet (Usman, 2003: 255).

Berdasarkan hasil penelitian dengan Bapak Dewa Ketut Kusuma Dewa, Kepala Bagian Kredit di PT. BPR Saptacristy Utama pada tanggal, 16 November 2020 menyatakan, untuk meningkatkan kualitas kredit, bank memberikan restrukturisasi kepada debitur dengan melakukan perubahan syarat-syarat addendum kredit yang dimana bank dan debitur telah sepakat untuk menyetujui mengadakan perubahan dan atau tambahan dalam perjanjian kredit. Addendum merupakan istilah hukum yang lazim digunakan dalam perihal pembuatan perjanjian. 
Dalam pembuatan addendum ini dilakukan karena adanya perubahan dari isi perjanjian pokok, atau karena ada beberapa perjanjian kredit yang belum diatur dalam perjanjian pokoknya. Namun dalam perjanjian kredit pembuatan addendum umumnya dibuat dikarenakan dari pihak debitur rnulai merasa tidak sanggup untuk membayar angsurannya, baik maupun bunganya. Secara umum pembuatan addendum dalam suaru perjanjian selalu terpisah dengan perjanjian pokok, namun secara hukum suatu addendum akrab dan menjadi bagian yang tidak bisa dipisahkan dari perjanjian utama.

\section{Implementasi Peraturan Otoritas Jasa Keuangan Nomor 11/POJK.03/2020 terhadap PT. BPR Saptacristy Utama}

Debitur yang mendapat perlakuan khusus dalam peraturan otoritas jasa keuangan adalah debitur yang mengalami kesulitan pembayaran ke bank karena debitur tersebut terkena dampak perkembangan virus corona (COVID-19). Peraturan Otoritas Jasa Keuangan Nornor 1 1/POJK.03/2020 tentang Stimulus perekonomian nasional sebagai kebijakan countercyclical dampak penyebaran corona virus disease 2019. Dalam peraturan otoritasjasa keuangan tersebut, kualitas kredit atau pembiayaan yang direstrukturisasi bisa ditentukan lancar bila diberikan untuk debitur yang terdampak penyebaran Virus Corona (COVID19). Restrukturisasi kredit adalah upaya perbaikan yang dilakukan Bank dalam kegiatan perkreditan terhadap debitur yang mengalami kesulitan untuk memenuhi kewajibannya yang diatur dalam Peraturan Otoritas Jasa Keuangan (Sihotang \& Sari, 2019). Kredit yang direstrukturisasi atau pembiayaan dilakukan sesuai kepada peraturan otoritas jasa keuangan mengenai penetapan kualitas jaminan, antara lain dengan cara:

a) Mendapatkan suku bunga rendah

b) Kelonggaran jangka waktu:

c) Potongan tunggakan pokok

d) Pengecilan tunggakan bunga

e) Menaikan fasilitas kredit atau pembiayaan

f) Pengubahan kredit atau pembiayaan menjadi ekuitas sementara.

Kredit di PT. BPR Saptacristy Utama pada tanggal, 16 November 2020 menyatakan, bentuk upaya penanganan kredit bermasalah di PT. BPR Saptacristy Utama berdasarkan Peraturan Otoritas Jasa Keuangan Nomor I 1/POJK.03/2020 adalah melakukan restrukturisasi dengan cara penundaan pembayaran pokok atau debitur membayar kredit sesuai dengan kemampuannya. Sehubungan dengan hal tersebut pihak bank melakukan perubahan atau penambahan syarat-syarat perjanjian kredit atau addendum untuk menetapkan kolektibilitas debitur menjadi lancar sejak dilakukan restrukturisasi sesuai dengan Peraturan Otoritas Jasa Keuangan Nomor 11/POJK.03/2020.

Sesuai kebijakan tersebut, Peraturan Otoritas Jasa Keuangan 11/POJK.03/2020 berlaku bagi debitur yang terserang akibat penyebaran Virus Corona (COVID-19) secara langsung maupun tidak langsung terkena dampak penyebaran Corona Virus Disease 2019 (COVID-19) meliputi bidang-bidang yang sangat besar resikonya melakukan kontak dengan orang banyak maupun berternu dengan wisatawan asing seperti pariwisata, perhotelan, perdagangan dan beberapa sektor lainnya. Akan tetapi, sebelum bank menerapkan kebijakan tersebut, Pasal 2 ayat (4) peraturan otoritas jasa keuangan 1 1/pojk.03/2020 dapat dipaharni bahwa bank dapat menerapkan ketentuan yang menolong perkembangan ekonomi sebagaimana maksud pada pasal tersebut, maka bank harus mempunyai pedoman dalam mengidentifikasi debitur yang terkena dampak Virus Corona, termasuk UMKM.

Berdasarkan pernyataan tersebut, bisa dipahami bahwa setiap bank akan memiliki pedoman yang berbeda-beda dalam menetapkan debitur yang terserang Virus Corona (COVID-19), serta menetapkan standar serta wi layah yang akan ditetapkan terdampak penyebaran Virus Corona (COVID-19). Namun pada PT. BPR Saptacristy Utama, tidak hanya sektor-sektor yang telah ditentukan saja yang dijadikan sebagai pedoman, melainkan halnya seperti debitur yang sehari-harinya sebagai karyawan ataupun buruh yang mempunyai kredit di PT. BPR Saptacristy Utama secara Jangsung maupun tidak langsung terkena penyebaran Virus Corona dikarenakan area-area seperti perusahaan-perusahaan juga terdampak penyebaran Virus tersebut. Sehingga banyak yang bekerja dirumah otomatis mengalami pemotongan pendapatan. Dan tidak sedikit karyawan tersebut memiliki pinjaman kredit kepada pihak bank. 
Setelah persyaratan debitur selesai, bank akan melaporkan, sesuai dengan pasal 9 Peraruran Otoritas Pengawas Keuangan No. II/POJ K.03/2020, yang dapat diartikan bahwa bank memberikan laporan berdasarkan situasi secara ofline pada setiap akhir bulan pada hari kerja sampai Maret 2021. Laporan yang disampaikan bank kepada Otoritas Jasa Keuangan adalah Japoran pendorong stimulus kredit, pembiayaan dan atau pendanaan lainnya yang diberikan sarnpai dengan akhir bulan. Laporan tersebut dievaluasi berdasarkan akurasi pembayaran. Dalam hal penyampaian secara offline laporan tersebut, protokol kesehatan tetap diperhatikan. Namun untuk PT. BPR Saptacristy Utama dalam menyampaikan laporan tersebut secara I minggu sekali kepada Otoritas Jasa Keuangan, yang dimana laporan tersebut berisi tentangjumlah debitur yang terdampak Virus Corona pada tahun 2020, baki debet dari debitur tersebut, kolektibilitas terakhir sebelum di restrukturisasi, dan sektor debitur tersebut yang berada di PT. BPR Saptacristy Utama.

\section{SIMPULAN DAN SARAN}

\section{Simpulan}

Berdasarkan hasil pembahasan dan analisis data penelitian, dapat disimpulkan bahw lmplikasi dari Peraturan Otoritas Jasa Keuangan Nomor 11/POJK.03/2020 terhadap perjanjian kredit, adanya hal yang belum diatur dalam perjanjian kredit pada saat memberikan restrukturisasi dapat dirubah dan atau ditambah dengan menggunakan perjanjian tambahan atau addendum. Dengan adanya addendum maka memudahkan pihak debitur dalam pengajuan keringan kreditnya. Pada pengimplikasian peraturan Otoritas Jasa Keuangan Nomor 11/POJK.03/2020 ini juga mempertimbangkan prinsip kehati-hatian didalamnya, untuk itu dalam pembuatan perjanjian kedua pihak harus sama-sama menyetujui perjanjian tersebut. Implementasi dari Peraturan Otoritas Jasa keuangan Nomor I 1/POJK.03/2020 terhadap PT. BPR Saptacristy Utama, dengan penerapan Peraturan Otoritas Jasa Keuangan tersebut PT. BPR Saptacrisry Utarna memberikan restrukturisasi dengan cara penundaan pembayaran pokok ataupun membayar sesuai dengan kemampuan debitur. Untuk prosedumya, mengharuskan bank mempunyai sistem operasional dan prosedur dalam menentukan debitur nya sebagai terdampak penyebaran Virus Corona. Terkait dengan hal itu setiap bank mempunyai kebijakan yang berbeda-beda dalam menangani kredit debiturnya dalam masa panderni Corona Virus Disease 2019 (COVID-19).

\section{Saran}

Berdasarkan simpulan diatas, maka saran yang dapat disampaikan dalam karya ilmiah ini adalah:

a. Bank sebaiknya pada masa pandemi Corona Virus Disease 2019 (COYID-19) ini, agar lebih bijak mengambil keputusan untuk memberikan restrukturisasi kepada debiturnya, hal ini dapat dilakukan dengan lebih meningkatkan pemantauan atau survey terhadap debitur yang ingin diberikan restrukturisasi apakah benar debitur tersebut terdampak penyebaran Corona Virus Disease 2019 (COVID-19) serta dilakukan evaluasi kembali apakah debitur sebelumnya mengalami kredit macet atau lancer.

b. Pemerintah hendaknya memberikan kepastian hukum kepada debitur sebagai bentuk penegakan hukum dan perlindungan hukum. Pemerintah harus secara tegas memberikan kepastian kebijakan yang akan dilaksanakan kepada bank, memberikan persyaratan yang jelas dan rinci, serta mempermudah dan melonggarkan persyaratan saat debitur melakukan pembayaran cicilan kreditnya.

\section{DAFTAR PUSTAKA}

Bahsan, M. (2001). Hukum Jaminan dan Kredit Perbankan Indonesia. PT Raja Grafindo Persada, Jakarta. Fajar, Mukti; Achmad, Y. (2015). Dualisme Penelitian Hukum (Normatif \& Empiris). Pustaka Pelajar. Yogyakarta.

Hamzah, R. A. (2019). Analisis Yuridis Penundaan Penagihan Kredit Oleh Bank Kepada Pelaku UMKM Yang Terkenana Bencana Alam Berdasarkan POJK No. 45/POJK.03/2017. Universitas Sumatera Utara.

Hermansyah. (2005). Hukum Perbankan Nasional Indonesia. Kencana Prenada Media Group, Jakarta. 
Hidayat, N. (2014). Tanggung Jawab Penanggung Dalam Perjanjian Kredit. Jurnal Ilmu Hukum Legal Opinion, Vol.2(4).

Kosasih, J. I. (2004). Mengupas Tuntas Kredit Komersial Dan Konsumtif Dalam Perjanjian Kredit Bank. Mandar Maju, Bandung.

Mulyati, E. (2016). Asas Keseimbangan Pada Perjanjian Kredit Perbankan Dengan Nasabah Pelaku Usaha Kecil. Jurnal Bina Mulia Hukum, Vol (1)(1).

Sihotang, B., \& Sari, E. K. (2019). Restrukturisasi Sebagai Penyelamatan Kredit Bermasalah Pada Bank. Prosiding Seminar Nasional Pakar Ke 2.

Sutarno. (2005). Aspek-aspek Hukum Perkreditan Pada Bank. Alfabeta, Bandung.

Usman, R. (2003). Aspek-aspek hukum perbankan di Indonesia (Cetakan ke-2). PT. Gramedia Pustaka, Jakarta.

Undang-Undang Nomor 10 Tahun 1998 Tentang Perubahan Atas Undang-Undang Nomor 7 Tahun 1992

Peraruran Otoritas Jasa Keuangan Nomor 11/POJK.03 ffahun 2020 Tentang Stimulus Perekonomian Nasional Sebagai Kebijakan Countercyclical Dampak Penyebaran Corona Virus Disease 2019. 